\title{
Quality Analysis of Work Life and Job Stress in Effect on The Performance of Employees
}

\author{
Isniar Budiarti \\ Management, Faculty of Economics and Business \\ Indonesian Computer University \\ Bandung, Indonesia \\ isniarbudiarti@gmail.com
}

\author{
Dani Setiawan \\ Management, Faculty of Economics and Business \\ Indonesian Computer University \\ Bandung, Indonesia
}

\begin{abstract}
- this study aims to obtain explanatory findings that have been tested by analyzing how (1) the quality of work life, Job Stress and employee performance, and (2) the quality of work life, and Job Stress influence on employee work performance. The research method used in this research is descriptive and verification. The subject of this research is employees in the $X Y Z$ private university environment in the city of Bandung. The method used in testing the conceptual hypothesis is by using path analysis, correlation analysis and determination coefficient and hypothesis testing through $T$ Test with the help of SPSS 21.0.0 for Windows software. So it can be seen that the quality of life of work life has a significant relationship to work performance, and Job Stress has a significant relationship to work performance, and the quality of work life and Job Stress has a significant effect on work performance.
\end{abstract}

\section{Keywords- Quality of Work Life, Job Stress, Work Performance}

\section{INTRODUCTION}

Organizations in carrying out various activities require a variety of resources, namely financial resources, material resources and human resources. Human Resources is one of the most important sources as the main actor and also an input of productivity in the organization, so that it can be said that the problem of human resources is not a small problem, so it must receive special attention. Human Resources synonymous with a company activity, employees and the times that demand to be more competitive, advanced, able to build a business and stay in the world of competition. Effective college management towards employee management determines the direction of achieving goals. Employees involved must be able to assist in achieving goals as an effort to improve work performance.

The quality of work life is a working condition as a result of the interaction between individuals and their work so as to make workers more productive and provide job satisfaction. References [1] say, the state of employees can meet their important needs and the ability to do depends on, 1) justice and care that supports employees; 2) the opportunity to use their abilities in full; 3) opportunity to manifest itself; 4) opportunity to play an active role in making important decisions involving their work

An employee's perception of their mental and physical health at work. Quality of Work Life is seen as, "A collection of employee perceptions of security in the workplace, job satisfaction, and conditions to develop that aim to enhance employee dignity." [2] Even although [3], states that the quality of work life is, "A process in which the response to the needs of employees to develop mechanisms that allow employees to give full advice and participate in making decisions and managing their work life in the company".

The work quality of life approach strives to meet the perceived needs of employees by providing fair, fair and supportive treatment, providing opportunities for every employee to use their abilities fully, providing opportunities to manifest themselves and providing opportunities to play an active role in making informed decisions involving work.

So it can be said that the quality of work life as a corporate responsibility to better utilize the skills and abilities of employees.

Job stress is basically often associated with understanding stress that occurs in the work environment, namely in the process of interaction between an employee and his work. According to [4] stress is, "A dynamic condition in which an individual is faced with opportunities, obstacles, or requests related to what is highly desirable and the results are considered uncertain and important". And response [5], that in "job adjustments are influenced by individual differences and psychological processes, as a consequence of environmental actions, situations or events that carry too many psychological and physical demands of a person".

While [6] states that "Work, stress as a condition of constancy that creates psychological and physical discontinuities, which can affect the emotions, thought processes and conditions of a person, this is caused by the work environment in which employees". or said "A condition of tension that creates a type of physical and psychological imbalance that affects the emotions, thought processes and conditions of an employee". [7]

It can be said that Job Stress is an emotional state of employees who are influenced by various factors: fulfillment of work, workload, working hours and individual conflict factors. And Job Stress can affect the work performance of employees towards the organization. If employees have high stress levels, work motivation is low and will affect work performance. 
References [8] state that in general performance or work performance is defined as "Individual success in work assignments including evaluating performance (work performance), productivity, knowledge, dependency, presence and independence". According to [1,9].

Reference [10] states that the idea of work performance is "The expected outcome of every employee behavior". Behavior related to employee work performance is a direct behavior with work tasks and objectives to achieve goals. Achievement is also called "Activities that produce effects, execution, actions or a series of actions to complete a job or how someone acts in carrying out a given task". [11].

References [12] say that performance appraisal is "The process of assessing employee performance and skills in this regard is related to work requirements, where employees are placed for administrative purposes, including placement, promotion, money wages and other actions that require different treatment between group members " whereas work achievement has terms that are often identified with performance terms.

If it is concluded that work performance is a result that can be achieved by employees in carrying out their work for a certain period.

\section{METHOD}

This research was conducted in one of the XYZ private universities in Bandung with the object being studied were employees. The population in this study is the entire population of permanent employees as much as 137 with the error rate that I use is $10 \%$, and obtained the sample studied amounted to 58 employees. The analysis used in this study is descriptive analysis to describe the characteristics of respondents and for the analysis of data processing methods of a character in the form of verifications collected through a questionnaire completed through observation and interviews.

Whereas the method used in conceptual hypothesis testing is using path analysis, correlation analysis and determination coefficient and hypothesis testing through $\mathrm{T}$ test with the help of SPSS 21.0.0 for Windows software. The line analysis used in this study will be broken down into two structural equations:

1) $X_{2}=\rho X_{2} X_{1}+\varepsilon_{1}$

2) $\mathrm{Y}=\rho \mathrm{YX}_{1}+\rho \mathrm{YX}_{2}+\varepsilon_{2}$

Information:

$\mathrm{Y}=$ work performance

$\mathrm{X}_{1} \quad=$ Quality of work life

$\mathrm{X}_{2} \quad=$ Job stress

$\rho \mathrm{X}_{2} \mathrm{X}_{1}=$ Path coefficient Quality of work life against job stress

$\rho \mathrm{YX}_{1}=$ Path coefficient Quality of work life on work performance

$\rho \mathrm{YX}_{2}=$ Path coefficient of Job Stress on work performance

$\varepsilon_{1,2}=$ Epsilon (influence other factors)

As for the dimensions and construction used in this study as shown in the following table:
TABLE 1. VARIABLES, DIMENSION, SIZE

\begin{tabular}{|c|c|c|}
\hline Variables & Dimensions & Size \\
\hline \multirow{9}{*}{$\begin{array}{l}\text { Quality of } \\
\text { Work life }\end{array}$} & Employee Participation & 1. Employee involvement \\
\hline & Career Development & 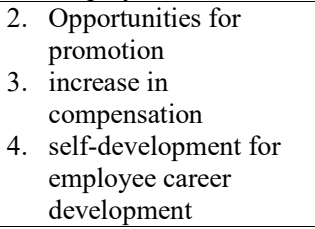 \\
\hline & Conflict Resolution & $\begin{array}{l}\text { 5. Completion of } \\
\text { employee work } \\
\text { conflicts }\end{array}$ \\
\hline & Communication & $\begin{array}{l}\text { 6ormal Path to group } \\
\text { face-to-face meetings }\end{array}$ \\
\hline & Occupational Health & $\begin{array}{l}\text { 7. Employee health } \\
\text { 8. control of occupational } \\
\text { health hazards }\end{array}$ \\
\hline & Work Safety & 9. Employee safety \\
\hline & Work Safety & $\begin{array}{l}\text { 10. Provides assurance of } \\
\text { employee job security } \\
\text { protection }\end{array}$ \\
\hline & $\begin{array}{l}\text { Appropriate } \\
\text { compensation }\end{array}$ & $\begin{array}{l}\text { 11. Provides compensation } \\
\text { eligibility }\end{array}$ \\
\hline & Pride & $\begin{array}{l}\text { 12. Grows a sense of pride } \\
\text { in work }\end{array}$ \\
\hline \multirow[t]{5}{*}{ Job Stress } & Workload & $\begin{array}{l}\text { 13. Levels of employee } \\
\text { workload }\end{array}$ \\
\hline & Task Characteristics & $\begin{array}{l}\text { 14. Level of employee task } \\
\text { difficulty }\end{array}$ \\
\hline & Conflict & $\begin{array}{l}\text { 15. Role of the company in } \\
\text { providing work } \\
\text { suitability }\end{array}$ \\
\hline & Organizational Structure & $\begin{array}{l}\text { 16. Clarity of position } \\
\text { 17. Corporate decision } \\
\text { making }\end{array}$ \\
\hline & Leadership style & 18. Leadership style \\
\hline \multirow[t]{6}{*}{$\begin{array}{l}\text { Work } \\
\text { Performance }\end{array}$} & Work Quality & 19. Employee quality \\
\hline & Productivity & $\begin{array}{l}\text { 20. The ability to complete } \\
\text { the work according to } \\
\text { the time }\end{array}$ \\
\hline & Knowledge & $\begin{array}{l}\text { 21. Ability knowledge } \\
\text { about the work }\end{array}$ \\
\hline & Can be relied & $\begin{array}{l}\text { 22. Ability to complete } \\
\text { work from a company }\end{array}$ \\
\hline & Attendance & $\begin{array}{l}\text { 23. Assessing employee } \\
\text { attendance }\end{array}$ \\
\hline & Employee Independence & $\begin{array}{l}\text { 24. Level of employee } \\
\text { independence }\end{array}$ \\
\hline
\end{tabular}

\section{RESULTS AND DISCUSSION}

Before you begin to format your paper, first write and save the content as a separate text file. Complete all content and organizational editing before formatting. Please note sections A-D below for more information on proofreading, spelling and grammar.

Keep your text and graphic files separate until after the text has been formatted and styled. Do not use hard tabs, and limit use of hard returns to only one return at the end of a paragraph. Do not add any kind of pagination anywhere in the paper. Do not number text heads-the template will do that for you. 
TABLE 2. RELATIONSHIP BETWEEN QUALITY OF WORK LIFE AND JOB STRESS

\begin{tabular}{|c|c|c|c|c|c|}
\hline \multicolumn{7}{|c|}{ Coefficients $^{\mathbf{a}}$} \\
\hline \multirow{2}{*}{ Model } & $\begin{array}{c}\text { Unstandardized } \\
\text { Coefficients }\end{array}$ & $\begin{array}{c}\text { Standardized } \\
\text { Coefficients }\end{array}$ & & \\
\cline { 2 - 4 } & B & $\begin{array}{c}\text { Std. } \\
\text { Error }\end{array}$ & Beta & t & Sig. \\
\hline $\begin{array}{c}1 \\
\text { (Construct) }\end{array}$ & 53,064 & 6,494 & & 8,171 &, 000 \\
\hline $\begin{array}{c}\text { Quality } \\
\text { Of work life }\end{array}$ & -.160 & .068 & -.299 & $-2,345$ &, 023 \\
\hline \multicolumn{2}{|c|}{$\begin{array}{c}\text { a. Dependent } \\
\text { Variable: Job Stress }\end{array}$} & & & & \\
\hline
\end{tabular}

The path coefficient ( $\rho$ X2X1) obtained is equal to -0.299 , the path coefficient is negative, indicating the relationship between the two is opposite. This means that employees who have better quality of work life tend to have lower Job Stress. This is in line with the results of research by that the quality of work life has a negative effect on Job Stress. [13].

TABLE 3. CONTRIBUTION OF THE INFLUENCE GIVEN BY THE QUALITY OF WORK LIFE TO JOB STRESS:

\section{Model Summary}

\begin{tabular}{|l|l|r|r|r|}
\hline Model & R & R Square & $\begin{array}{c}\text { Adjusted } R \\
\text { Square }\end{array}$ & $\begin{array}{c}\text { Std. Error of } \\
\text { the Estimate }\end{array}$ \\
\hline 1 &, $299^{\mathrm{a}}$ &, 089 &, 073 & 7,46301 \\
\hline
\end{tabular}

a. Predictors: (Constant), Quality of work life

b. Dependent Variable: Job Stress

In the table above, it can be seen that the $\mathrm{R}$ Square value obtained is equal to 0.089 , which means that the quality of work life contributes $8.9 \%$ to Job Stress, while the remaining $91.1 \%$ is the contribution of the influence given by other factors not examined. (epsilon $/ \varepsilon_{1}$ ).

The path equation which explains the relationship between the quality of work life and Job Stress is as follows:

$$
\mathrm{X}_{2}=-0,299 \mathrm{X}_{1}
$$

If presented in the form of a path diagram, the path coefficient and epsilon will appear as follows:

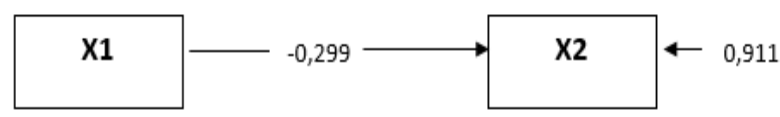

FIGURE 1. Pathway Relationship Diagram Between Quality of work life with job stress

Furthermore, the statistical test used to test this partial hypothesis is the $t$ test. The value of the table used as the critical value in this t test is 2.003 which is obtained from the $\mathrm{t}$ distribution table with $\alpha 5 \%$ and df (n (58) -k (1) -1) 56 for the two-party test. Summary of test results is presented in the following table:
TABLE 4. T TEST (PARTIAL) RELATIONSHIP TO WORK LIFE QUALITY WITH JOB STRESS

\begin{tabular}{|l|c|c|c|c|c|c|}
\hline Model & $\mathbf{t}_{\text {count }}$ & $\mathbf{t}_{\text {table }}$ & Sig. & $\boldsymbol{\alpha}$ & $\begin{array}{c}\text { Infor } \\
\text { mation }\end{array}$ & $\begin{array}{c}\text { Con } \\
\text { clusion }\end{array}$ \\
\hline $\begin{array}{l}\mathrm{X}_{1} \rightarrow \\
\mathrm{X}_{2}\end{array}$ & $-2,345$ & $-2,003$ & 0,023 & 0,05 & $\begin{array}{c}\text { Ho } \\
\text { rejected }\end{array}$ & $\begin{array}{c}\text { Signifi } \\
\text { cant }\end{array}$ \\
\hline
\end{tabular}

Source: SPSS.21 data attached, 2017

In table 3.3 , the value of tcount is -2.345 with a significance value of 0.03 , because thitung $(-2.345)$ is smaller than negative ttable $(-2.003)$ then the error rate of $5 \%$ is decided to reject Ho and so Ha is accepted. These results show that there is a significant relationship between the quality of work life and the stress of employee work at XYZ University in Bandung. The negative path coefficient indicates that employees who have better quality of work life tend to have lower Job Stress.

Based on the results of data processing using the SPSS 21.0 program, Analysis of the Effect of Quality of work life and Job Stress on work performance at XYZ University, obtained the following matrix results:

TABLE 5. CORRELATION MATRIX

\begin{tabular}{|c|c|c|c|c|}
\hline \multicolumn{5}{|c|}{ Correlations } \\
\hline & & Quality & & Work \\
\hline & & $\begin{array}{c}\text { Of } \\
\text { Work } \\
\text { Life } \\
\end{array}$ & $\begin{array}{c}\text { Job } \\
\text { Stress }\end{array}$ & Performance \\
\hline \multirow[t]{3}{*}{$\begin{array}{l}\text { Quality of } \\
\text { Work Life }\end{array}$} & $\begin{array}{c}\text { Pearson } \\
\text { Correlation }\end{array}$ & 1 & -.299 & $.772 * *$ \\
\hline & Sig. (2-tiled) & & .023 & .000 \\
\hline & $\mathrm{N}$ & 58 & 58 & 58 \\
\hline \multirow[t]{3}{*}{ Job Stress } & $\begin{array}{c}\text { Pearson } \\
\text { Correlation }\end{array}$ & -.299 & 1 & $-.576 * *$ \\
\hline & Sig. (2-tiled) & .023 & & .000 \\
\hline & $\mathrm{N}$ & 58 & 58 & 58 \\
\hline \multirow[t]{3}{*}{$\begin{array}{c}\text { Work } \\
\text { Performance }\end{array}$} & $\begin{array}{c}\text { Pearson } \\
\text { Correlation }\end{array}$ & $.772 * *$ & $\begin{array}{c}- \\
.576^{* *} \\
\end{array}$ & 1 \\
\hline & Sig. (2-tiled) & .000 & .000 & \\
\hline & $\mathrm{N}$ & 58 & 58 & 58 \\
\hline \multicolumn{3}{|c|}{$\begin{array}{c}* \text { * Correlation is significant at the } 0.05 \\
\text { level (2-tiled) }\end{array}$} & & \\
\hline \multicolumn{3}{|c|}{$\begin{array}{l}\text { **. Correlation is significant at the } 0.01 \\
\text { level (2-tiled) }\end{array}$} & & \\
\hline
\end{tabular}

Source: SPSS.21 data attached, 2017

The correlation coefficients presented in the table above can be interpreted that:

1) The relationship between the quality of work life and work performance.

Correlation coefficient between the quality of work life and work performance is 0.772 and is included in the strong relationship category because it is in the correlation interval between $0.60-0.799$. Positive correlation coefficient indicates that the relationship between the two is unidirectional, meaning that the better the quality of work life, the better the work performance. Based on these results, it can be concluded 
that there is a strong relationship between the quality of work life and work performance.

2) The relationship between Job Stress and work performance.

The correlation coefficient between Job Stress and work performance is equal to -0.576 and is included in the category of a fairly strong relationship, because it is in the correlation interval between $0.40-0.599$. The negative correlation coefficient that shows the relationship between the two is the opposite, meaning that the lower the Job Stress, the work performance will increase. Based on these results, it can be concluded that there is a fairly strong relationship between Job Stress and work performance.

After knowing the correlation coefficient of each exogenous variable with the endogenous variable, the next step is to calculate the path coefficient $(\rho)$ and calculate the amount of the contribution of the combined influence (determination coefficient / R2) given by the exogenous variable to the endogenous variable. The results of data processing using the SPSS 21.0 program, can be seen in the following table:

TABLE 6. COEFFICIENT OF QUALITY OF WORK LIFE QUALITY AND JOB STRESS AGAINST WORK PERFORMANCE AT XYZ UNIVERSITY EMPLOYEES

\begin{tabular}{|c|c|c|c|c|c|}
\hline \multicolumn{6}{|c|}{ Coefficients $^{a}$} \\
\hline \multirow[b]{2}{*}{ Model } & \multicolumn{2}{|c|}{$\begin{array}{l}\text { Unstandardized } \\
\text { Coefficients }\end{array}$} & \multirow{2}{*}{$\begin{array}{c}\begin{array}{c}\text { Standardized } \\
\text { Coefficients }\end{array} \\
\text { Beta }\end{array}$} & \multirow[b]{2}{*}{$\mathrm{t}$} & \multirow[b]{2}{*}{ Sig. } \\
\hline & B & $\begin{array}{l}\text { Std. } \\
\text { Error }\end{array}$ & & & \\
\hline $\begin{array}{c}1 \\
\text { (Construct) }\end{array}$ & 26,562 & 5,193 & & 5,115 &, 000 \\
\hline $\begin{array}{l}\text { Quality of } \\
\text { Work Life }\end{array}$ & ,344 & 039 & ,658 & 8,902 &, 000 \\
\hline $\begin{array}{l}\text { Job } \\
\text { Stress }\end{array}$ &,- 370 & 072 & 379 & $-5,121$ & 000 \\
\hline $\begin{array}{r}\text { a. Dep } \\
\text { Variable: } \\
\text { Perform }\end{array}$ & $\begin{array}{l}\text { adent } \\
\text { Nork } \\
\text { nce }\end{array}$ & & & & \\
\hline
\end{tabular}

Source: SPSS.21 data attached, 2017

In the table, it can be seen that the path coefficient for the quality of work life (pyx 1 ) is 0.658 and the path coefficient for Job Stress ( $\rho y x 2$ ) is -0.379 . Line equations that explain the effect of the quality of work life and Job Stress on work performance are as follows:

$$
\mathrm{Y}=0,658 \mathrm{X}_{1}-0,379 \mathrm{X}_{2}
$$

If presented in the form of a path diagram, the correlation value (r), path coefficient $(\rho)$ and epsilon $(\varepsilon)$ will appear as follows:

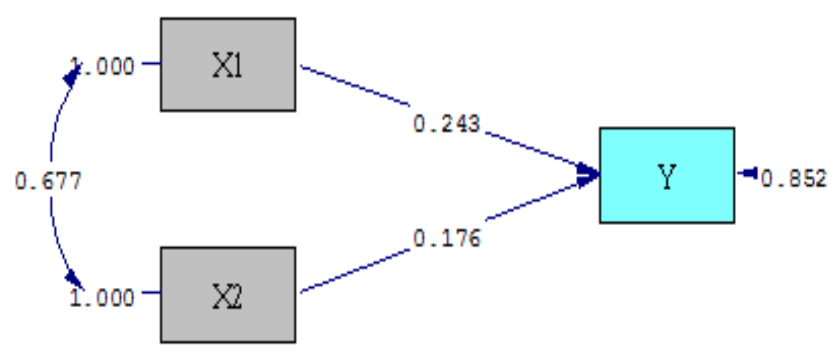

FIGURE 2. Work life quality and job stress diagram on the work performance of university xyz employees

Based on the results of partial hypothesis testing, it is known that the quality of work life and Job Stress has a significant effect on work performance at XYZ University. To find out more details about the magnitude of the direct effect contribution and the indirect effect given by the exogenous variable to the endogenous variables, it can be seen in the recapitulation of the calculation of the amount of direct and indirect influence contribution is presented in the following table:

TABLE 7. LARGE RECAPITULATION OF DIRECT AND INDIRECT INFLUENCE CONTRIBUTIONS FROM THE QUALITY OF WORK LIFE AND JOB STRESS AGAINST EMPLOYEE PERFORMANCE AT XYZ UNIVERSITY

\begin{tabular}{|c|c|c|c|c|c|}
\hline \multirow{2}{*}{ Model } & \multirow{2}{*}{$\begin{array}{c}\text { Path } \\
\text { Coeffiecient }\end{array}$} & \multirow{2}{*}{$\begin{array}{c}\text { Direct } \\
\text { Effect }\end{array}$} & \multicolumn{2}{|c|}{$\begin{array}{c}\text { Indirect } \\
\text { Effect }\end{array}$} & \multirow{2}{*}{$\begin{array}{c}\text { Total } \\
\text { Effect (\%) }\end{array}$} \\
\cline { 4 - 5 } & & $\mathbf{X}_{1}$ & $\mathbf{X}_{2}$ & \\
\hline $\mathrm{X}_{1} \rightarrow \mathrm{Y}$ & 0,658 & $43,3 \%$ & - & $4,9 \%$ & $48,3 \%$ \\
\hline $\mathrm{X}_{2} \rightarrow \mathrm{Y}$ & $-0,379$ & $14,3 \%$ & $4,9 \%$ & - & $19,3 \%$ \\
\hline \multicolumn{7}{|c|}{ Total Effect } & $\mathbf{7 2 , 6 \%}$ \\
\hline
\end{tabular}

Source: Questionnaire data were processed using SPSS and MS. Excel

In the table above, it can be seen that the quality of work life contributes $48.3 \%$ to work performance while Job Stress contributes $19.3 \%$ to achievement, so the overall result of the determination coefficient is $72.6 \%$ meaning that there are still other variables that affect XYZ University employee work performance in addition to variable quality of work life and Job Stress such as work motivation, work environment, work discipline, job satisfaction and work family conflict.

Whereas in the partial hypothesis test (t-test) is carried out to prove whether the quality of work life and Job Stress partially have a significant effect on work performance using the SPSS program, the following results are obtained:

TABLE 8. PARTIAL HYPOTHESIS TEST (UJI T)

\begin{tabular}{|c|c|c|c|c|c|}
\hline \multicolumn{6}{|c|}{ Coefficients $^{\mathrm{a}}$} \\
\hline \multirow[t]{2}{*}{ Model } & \multicolumn{2}{|c|}{$\begin{array}{c}\text { Unstandardized } \\
\text { Coefficients }\end{array}$} & \multirow{2}{*}{$\begin{array}{c}\begin{array}{c}\text { Standardized } \\
\text { Coefficients }\end{array} \\
\text { Beta }\end{array}$} & \multirow[b]{2}{*}{$\mathbf{t}$} & \multirow[b]{2}{*}{ Sig. } \\
\hline & B & $\begin{array}{l}\text { Std. } \\
\text { Error }\end{array}$ & & & \\
\hline $1 \quad$ (Construct) & 26,562 & 5,193 & & 5,115 &, 000 \\
\hline $\begin{array}{l}\text { Quality of } \\
\text { Work Life }\end{array}$ &, 344 & ,039 & ,658 & 8,902 &, 000 \\
\hline Job Stress &,- 370 & 072 & ,379 & $\begin{array}{c}- \\
5,121\end{array}$ &, 000 \\
\hline
\end{tabular}




\begin{tabular}{|l|l|l|l|l|}
\hline $\begin{array}{l}\text { a. Dependent Variable: } \\
\text { Work Performance }\end{array}$ & & & & \\
\hline
\end{tabular}

Source: SPSS.21 data attached, 2017

Influence of Quality of work life statistically it can be seen that tcount of work life quality is 8.902 with significance value close to zero, because $t$ hitung $(8.902)>t$ table (2.004), these results indicate that there is a significant relationship between the quality of work life with employee work performance at the University XYZ. Positive path coefficient analysis shows that employees who have better quality of work life tend to show better work performance.

The results of this study are in line with, where there is a positive and significant relationship between the quality of work life and employee performance. [14]. Likewise the results of the research, where the quality of work life has a positive and significant influence on employee performance. [15].

The effect of Job Stress statistically, the Job Stress tcount is -5.121 with a significance value approachingol, because $\mathrm{t}$ hitung $(-5.345)<\mathrm{of}$ negative $\mathrm{t}$ table $(-2.004)$, these results indicate that there is a significant relationship between Job Stress and employee performance at XYZ University. The negative path coefficient indicates that employees who have low Job Stress tend to show better work performance. and work stress affects work performance. [16]. other studies found that Job Stress negatively affects work performance. [17]

\section{CONCLUSION}

Based on the results of the research and discussion that has been described regarding the quality of work life, Job Stress and work performance of University XYZ employees, it can be concluded that, efforts to improve the quality of work life of employees at the University XYZ have been sufficient, meaning that the organization technically and humanely brings quality better work life

\section{REFERENCES}

[1] Dessler Gary. Manajemen Sumber Daya Manusia. Edisi Kesepuluh Jilid Dua. Jakarta: PT Indeks.2009

[2] Ita Maemunah, Upiek Haeryah Sadkar, Herry Ryana. Effect of Work Life Quality on Work Motivation. BARISTA. July 2015; 2 (1): 80-92

[3] Robbins Stephen P. Judge. Organizational behavior. Jakarta: Salemba Empat. 2007.

[4] Robbins. Stephen P. Organizational Behavior. PT Index: Gramedia Group. Jakarta. 2008.

[5] Mangkunegara, Anwar Prabu. Human Resources Company. Bandung: PT Remaja Rosdakarya. 2005.

[6] Rivai, Veithzal. Human Resource Management for Companies from Theory to Practice. Jakarta: Raja Grafindo. 2009

[7] Gaol. CHR. Jimmy L. A to Z Human Capital Concept, Theory, and Development in the Context of Public and Business Organizations. Jakarta: PT. Gramedia Widiasarana.2014.

[8] Maier, Norman R.F. Psychology in Industry. Boston: Houghtin Mifflin. 1965.

[9] Dessler Gary. Manajemen Sumber Daya Manusia. Edisi Kesepuluh Jilid Dua. Jakarta: PT Indeks.2009.
[10] Gibson, James L., John M. Ivancevich and James H. Donnelly, Jr. Organization, Behavior, Structure, Process, (Transfer of Nunuk Adiarni). Jakarta.: Literacy Bina Aksara. 1996

[11] Dali Gulo. Psychology Dictionary. Bandung: Tonis Publisher. 1982.

[12] Moekijat. Training and Human Resource Development. Bandung: Mandar Forward. 1994.

[13] Rethinam, G.S. \& Ismail. M. Constructs of Quality of Work Life: A Perspective of Information and Technology Professionals. European Journalof Social Sciences. 2008; Vol.7 No. 1, (online).

[14] Elmuti, Dean., Yunus Kathawala. An Investigation into Effects of ISO 9000 on Participants: Attitudes and Work Performance. Production and Inventory Management Journal. Second Quarter. 1997; Vol. 4 No.4, pp 229-243.

[15] Kusuma W, Putri Cahya, Kusdi Raharjdo and Arik Prasetya. Effect of Job Stress and Quality of Work Life on Job Satisfaction and Employee Performance (Study on non-medical employees of Ibnu Sina Hospital in Gresik). Journal of Business Administration (JAB). 2015; Vol. 1 No. 1, pp 1-9.

[16] Karim, Nurlia. Job Stress Influence on Employee Performance (study at Café Bambu Express Manado. EMBA Journal 513. ISSN 23031174. December 2013; Vol.1 No.4, pp 513-522.

[17] Yusianto. Analysis of the Effect of Job Stress on Job Performance of Teaching Staff. Postgraduate Program in Master of Industrial Engineering, Indonesian Islamic University. Yogyakarta. 2008. 